Original Research Paper

\title{
Absorption of Food Along the Guts of Parachanna obscura and Clarias gariepinus
}

\author{
${ }^{1}$ Eunice O. Idowu, ${ }^{1}$ Adewumi A. Adejoke, ${ }^{1}$ Josephine B. Edward, ${ }^{1,2}$ Dolapo F. Odeyemi, \\ ${ }^{1}$ Folasade A. Ola-Oladimeji and ${ }^{1}$ Akintayo Joshua Oluwaseun \\ ${ }^{1}$ Department of Zoology and Environmental Biology, \\ Faculty of Science, Ekiti State University, Ado Ekiti, Ekiti State, Nigeria \\ ${ }^{2}$ Department of Science Laboratory Technology, (Biotechnology Option), \\ Faculty of Science, Ekiti State University, Ado Ekiti, Ekiti State, Nigeria
}

\author{
Article history \\ Received: 12-11-2019 \\ Revised: 10-01-2020 \\ Accepted: 24-02-2020 \\ Corresponding Author: \\ Eunice O. Idowu \\ Department of Zoology and \\ Environmental Biology, \\ Faculty of Science, Ekiti State \\ University, Ado Ekiti, Ekiti \\ State, Nigeria \\ Tell: 08039422005 \\ Email: eunice.idowu@eksu.edu.ng
}

\begin{abstract}
The knowledge of feeding habit and absorption of food in the gut of fish is important for fish farmers to boost their production and meet the ever increasing demand for man consumption. The carbohydrate, protein and lipid contents of the food ingested and their absorption in the intestine of Parachanna obscura and Clarias gareipinus inhabiting Ogbese River in Ekiti State were investigated. For Parachanna obscura, total protein of the ingested food was $64.54 \%$, total carbohydrate $20.20 \%$ while the total lipid in the stomach content was $6.12 \%$ of organic matter. The total percentages of the food absorbed were $76.4 \%$ protein, $35.9 \%$ carbohydrate and $25.2 \%$ lipid. For Clarias gariepinus, total protein of the ingested food was $60.87 \%$, total carbohydrate $30.42 \%$ while total lipid in the stomach content was $3.30 \%$ of organic matter. The total percentages of the food absorbed were $68.0 \%$ protein, $45.8 \%$ carbohydrate and $24.5 \%$ lipid. In both fish species the absorption of protein, carbohydrate and lipid occurred mostly in the foregut (the first one-third of the intestine). In Parachanna obscura, the foregut had the highest percentage absorption (59\% protein, $24 \%$ carbohydrate and $15 \%$ lipid), while the hindgut had the lowest percentage absorption (4\% protein, $4.6 \%$ carbohydrate and $3.3 \%$ lipid). In Clarias gariepinus, the foregut had the highest percentage absorption (41\% protein, $34 \%$ carbohydrate and $14 \%$ lipid) while the hindgut had the lowest percentage absorption (4.1\% protein, $3.6 \%$ carbohydrate and $3.3 \%$ lipid). The nutrients contents (protein, carbohydrate and lipid) of the food in Parachanna obscura were significantly different $(\mathrm{P}>0.05)$ from the nutrients (protein, carbohydrate and lipid) in the food of Clarias gariepinus. This will provide base-line information useful in artificial food formulation and culture of suitable live organisms for the species during culture of either species.
\end{abstract}

Keywords: Fish, Absorption, Food, Gut, Protein, Carbohydrate, Fat

\section{Introduction}

Feeding is the process of taking in food; Food can be defined as any substance consumed to provide nutritional support for the body (Rabanal et al., 2004). Digestion is the process of modifying and/or hydrolyzing feed and food polymers into molecules and elements that can be absorbed across the intestinal wall (Portella and Dabrowski, 2008). Absorption is the process of assimilating food substance into the cells, tissues and organs in the body of fish (Peter et al., 2004).
Knowledge about what fish eats aids in understanding digestion and absorption in their gut (Platell and Polter, 2001). Some fish species feed on dead items (scavengers), others on living material, some feed solely on micro- organisms, others on larger plants and animals and some are opportunistic eating whatever they can find and they undergo different types of digestion of food. Basically, fishes are classified into herbivores, omnivores and carnivores based on the nature of food taken. The morphology of the digestive apparatus is an adaptation to their food and feeding habits (Russo et al., 
2007). These three classes are defined as follows; Herbivorous fish is a group of fishes that eat plant materials. Example include tilapia (Oreochromis niloticus), parrot fish (Chlocucus microzhinos), gold fish (Carassium auratus), surgeon fish (Acanthurus lineatus) etc. Carnivorous fishes are fishes which feed majorly on flesh. Example of these fishes include tiger fish (Hydrocynus vittatus), African pike (Hepsetus odoe), cuttle fish (Polpsus bimaculatus), white shark (Carcharodon carchucians) etc. Omnivorous fishes are fishes that can eat flesh and plant materials, example include angel fish (Pterophylum leopoldi), tiger barbs (Puntigrus tetrazona), carp (Cyprinus carpio), (Ichtalacus punctatus) (Amber, 2013).

Food absorption is known to vary with fish species. Bligh and Dyer (1959) reported that gold fish Chlocucus microzhinos absorbed $60 \%$ of carbohydrate, $79 \%$ of protein and also $40 \%$ of lipid thus loosing $40 \%, 20 \%$ and $60 \%$ of carbohydrate, protein and lipid respectively. Oreochromis mossambicus assimilated $63 \%$ organic matter, $77 \%$ protein and $63 \%$ carbohydrate in its food implying that 23-27\% was lost (Bowen, 1981). Tilapia rendalli assimilated $63-70 \%$ of the dry weight in the apical segments of Ceratophyllum demersum thus losing 30-37\% (Caulton, 1978). Oreochromis aureus assimilated about $55 \%$ and $77 \%$ of carbon in green and blue green algae, thus loosing $45 \%$ and $33 \%$ (Tanaka et al., 1981). Also a similar research was carried out by Moriarty (1973) and he reported that Oreochromis niloticus assimilated about $50 \%$ of carbon in green algae and $80 \%$ of blue green algae thus loosing $50 \%$ and $20 \%$ respectively. Sarotherondon galilaleus absorbed about $88 \%, 78 \%, 84 \%$ and $37 \%$ of the carbohydrate, protein, lipid and crude fiber respectively in its diet thus losing 12-63\% (Akintunde, 1982). Brunson (1998) fed Clarias gariepinus with conventional feedstuffs of groundnut cake and maize. He reported that about $68 \%$ of carbohydrate, $52 \%$ of protein, $38 \%$ of lipid was absorbed in the intestine thus losing $32 \%, 48 \%$ and $62 \% \mathrm{f}$ carbohydrate, protein and lipid respectively. In Heterotis niloticus about $65 \%$ of protein, $40 \%$ carbohydrate and $78 \%$ lipid consumed were absorbed thus $22-60 \%$ was lost (Ugwumba, 1996). Hepsetus odoe absorbed about $72 \%$ of protein, $63 \%$ of carbohydrate and $51 \%$ of lipid thus losing $28 \%$ of protein, $37 \%$ of carbohydrate and $49 \%$ of lipid (Idowu, 2011)

Cat fish (Clarias gariepinus) is an omnivorous fresh water fish. It is a popular delicacy in Nigeria. It is a prominent culture species because of its fast growth rate and resistance to diseases and stress factors like over stocking and poor water quality (Olojo et al., 2005). It is named cat fish because they possess prominent barbels which resemble cat's whiskers. It has slender body (Ahmed, 2013). The Snake head fish, (Parachanna obscura) is a medium sized carnivorous fish that has an elongated shape tapered at both ends and is covered with circular scales (cycloid). The adult fish feed primarily on other fish up to half their size while juveniles feed on insect larvae, prawns, copepods and insects (Fiogbe, 2013).

Studies on food and feeding habit of Clarias gariepinus showed that it feeds mostly on zooplanktons (Ameigheme, 2005; Adeyemi, 2009). Parachanna obscura is a carnivorous fish. Studies conducted on food and feeding habits of Parachanna obscura in cross River state Nigeria between February and April 2009 revealed that the species feed mostly on food from animal origin (George et al., 2009). The type and length of a fish gut is a function of the type of food it consumes (Elliott and Bellwood, 2003; Idowu, 2011).

The quantity and the quality of food given to different types of fish have a drastic effect on how these foods are absorbed in their gut (Abowei and Ekubo, 2011). The amount of food given to fish determines the amount of food in the stomach of fish which is prior to how these nutrients are absorbed.

Fish is known to be the commonest and readily available source of protein in the diets of Nigerians which is mostly consumed compared to the other sources of protein such as cow and goat. This encourages artificial rearing of fish in order to meet its increasing demand. Therefore, it is necessary to have the knowledge of the food, feeding habit as well as absorption of food and nutritional requirements for optimum growth of fish. This will help in the formulation of fish feed by fish farmers to boost their production of fish, meet the demand for man consumption and subsequently boost the economy.

\section{Materials and Methods}

\section{Study Area}

Ogbese River flows from Ekiti State through Ogbese town in Akure North Local Government Area, Ondo State. It has an annual rainfall of about $1600 \mathrm{~mm}$ to 2100 $\mathrm{mm}$, which covers the month of April to October and drainage area of $2039 \mathrm{~km}$. the mean daily maximum temperature range from $30^{\circ} \mathrm{C}$ to $35^{\circ} \mathrm{C}$ while the mean daily minimum temperature range from $21^{\circ} \mathrm{C}$ to $26^{\circ} \mathrm{C}$ (Philips, 1996; Bord, 2013). Ogbese River also serves as source of water supply to the neighboring rural communities. The River is used for irrigation of farm lands and as a means of livelihood for local fishermen. Artisanal fishery is also practiced at the River using traps, set and cast nets, hook and line. Species of fish in the River include Tilapia zillii, Sarotherodon niloticus, Clarias gariepinus, Hepsetus odoe, Parachanna obscura etc (Adewumi et al., 2014).

\section{Collection of Fish Samples}

A total number of 88 Clarias gariepinus and 74 Parachanna obscura samples were collected from 
fishermen between June 2017 and September 2017. These samples were collected on weekly basis (1-3 times a week based on the availability of the fish samples) from the landing centers of fishermen. They were brought to the department of Zoology and Environmental Biology Laboratory for analysis.

\section{Analysis of Samples}

In the laboratory, the total length, the standard length (beginning from snout to the end of caudal peduncle) (Schineider, 1990) were taken to the nearest $0.1 \mathrm{~cm}$ by the use of a measuring board. The weight of individual fish samples was taken with an electronic weighing balance to the nearest $0.1 \mathrm{~g}$.

\section{Analysis of Stomach Contents}

The fish was dissected with a pair of pointed scissors. The stomach was removed by slitting the fish from the throat to anus. The fullness of stomach was noted and classified as full, three- quarter full, half- full, one quarter full or empty stomach.

\section{Chemical Composition and Energy Level of Stomach Contents, Intestinal Contents and Feacal samples}

After the length of the gastro intestinal tract was cut into sections of stomach, foregut, mid gut and hindgut, the contents of the sections i.e., stomach, fore, mid and hind gut were then emptied into a Petri dish. Samples of contents of the stomach and various sections of the intestine (foregut, midgut, and hindgut) and feaces were dried at $70^{\circ} \mathrm{C}$ for $24 \mathrm{~h}$. Feacal samples were obtained by pressing slightly the anal region of each specimen. The moisture free samples were grounded in a mortal and sealed in small dry envelope and kept properly prior to proximate analysis.

The method of Kaushik and Hynes (1968) was employed to extract protein from the dried samples. Extraction was carried out for $48 \mathrm{~h}$ at room temperature with $0.1 \mathrm{~m}$ sodium hydroxide $(\mathrm{NaOH})$, purified by precipitation with Trichloroacetic Acid (TCA) and quantified by Miller's (1959) modification of Lowry's assay, as described by Clark (1983). Carbohydrates in the sample were determined by a colorimetric technique using acid orcinol reagent. Lipids were quantified by the rapid total lipid extraction method of Bligh and Dyer (1959). Energy content of each sample was determined by measuring the amount of heat released during combustion of the sample using a Gallenkamp Ballistic Bomb Calorimeter following the procedure in the Calorimeter manual. The results were expressed as kcal/g.

\section{Absorption of Food along the Gut}

In calculating percentage absorption of ingested food, the percentage of each nutrient component in the stomach was regarded as the amount ingested while the percentage in feaces was regarded as the amount egested. The difference between the amounts in the various sections of the intestine relative to the amount in the stomach was attributed to absorption in the various sections of the intestines. Percentage absorption was calculated for protein, carbohydrate and lipid.

\section{Statistical Analysis}

The minimum, maximum and mean value of total length, standard length, intestinal length and weight of both Parachanna obscura and Clarias gariepinus were determined. Correlated coefficients of nutrients were determined from the two species studied to know if these are significantly different from each other or not using ANOVA with Duncan Multiple Range Test (DMRT).

\section{Results}

\section{Proximate Analysis of Stomach and Intestinal Contents}

The nutrients composition of food ingested by both fish species i.e., Parachanna obscura and Clarias gariepinus and percentage absorption in their gut are presented in Table 1a and 2a respectively. Average weight of Parachanna obscura is $291.48 \mathrm{~g}$ and for Clarias gariepinus it is $321.82 \mathrm{~g}$. Average standard lengths is $26.41 \mathrm{~cm}$ for Parachanna obscura and $30.43 \mathrm{~cm}$ for Clarias gariepinus. For Parachanna obscura the mean intestinal length is $60.3 \%$ of total length of the body while for Clarias gariepinus it's $89.3 \%$ of total length of the body.

Total protein in the stomach content of Parachanna obscura is $64.54 \%$, total carbohydrate is $20.20 \%$, total lipid is $6.12 \%$ and total ash is $7.00 \%$, total moisture content is $2.14 \%$. Fiber was not detected in the stomach and the value of Energy is $2.96 \mathrm{kcal} / \mathrm{g}$ in the stomach organic matter as shown in Table 1a. While in Clarias gariepinus, total protein in the stomach is $60.87 \%$, total carbohydrate is $30.42 \%$ and total lipid is $3.30 \%$, total ash is $3.00 \%$, total moisture content is $2.41 \%$. Fiber was not detected in the stomach and the value of Energy is $2.83 \mathrm{kcal} / \mathrm{g}$ in the stomach organic matter as shown in Table $2 \mathrm{a}$.

\section{Absorption of Food}

As the food progressed from the stomach of Parachanna obscura through various sections of the intestine, the amount of protein, carbohydrate and lipid decreased until it finally became feaces as presented in Table $1 \mathrm{~b}$ above. By the time the food became feaces, total of $76.4 \%$ protein, $35.9 \%$ carbohydrate and $25.2 \%$ lipid had been absorbed (Table 1b). The foregut had the highest percentage absorption (59\% protein, $24 \%$ carbohydrate and $15 \%$ lipid) followed by midgut (14\% 
protein, $7 \%$ carbohydrate and $7 \%$ lipid), while the hindgut had the lowest (4\% protein, $4.6 \%$ carbohydrate and $3.3 \%$ lipid). So also, as food progressed from the stomach of Clarias gariepinus through various sections of intestine i.e., foregut, midgut and hindgut, the amount of protein, carbohydrate and lipid decreased until it finally became feaces (Table 2b). By the time the food became feaces, total of $68.0 \%$ protein, $45.8 \%$ carbohydrate and $24.5 \%$ lipid had been absorbed (Table $2 \mathrm{~b}$ ).

The foregut had the highest percentage absorption (41\% protein, $34 \%$ carbohydrate and $14 \%$ lipid) followed by midgut $(23.2 \%$ protein, $7.9 \%$ carbohydrate and $7.3 \%$ lipid), while the hindgut had the lowest percentage absorption (4.1\% protein, $3.6 \%$ carbohydrate and $3.3 \%$ lipid). Absorption of protein is the highest followed by carbohydrate then lipid. This statement is true for both fish species.

The comparisons of the nutrients in the two species were tabled out in Table 3. Protein, carbohydrate, lipid, fiber and energy were found to be significantly different in both species, which were marked by different superscript. i.e. Parachanna obscura nutrients are significantly different from Clarias gariepinus nutrients (Table 3). Moreover for other nutrients like ash and moisture content they are not significantly different. For Parachanna obscura, ash value is 36.40 a and for Clarias gariepinus $32.16 \mathrm{a}$ and moisture content value for both fish species 8.80c and 9.49c for Parachanna obscura and Clarias gariepinus respectively. The results were marked by similar superscript.

Table 1a: Proximate Composition of food of Parachanna obscura collected from Ogbese River

\begin{tabular}{llllll}
\hline Parameters measured & Stomach & Foregut & Midgut & Hindgut & Feaces \\
\hline \%Ash & 7.00 & 40.92 & 46.53 & 48.15 & 49.75 \\
\% Moisture content & 2.14 & 7.65 & 9.85 & 9.98 & 14.38 \\
\% Crude Protein & 64.54 & 26.80 & 17.78 & 15.22 & 12.02 \\
\% Fat & 6.12 & 4.22 & 4.78 & 4.58 & 2.57 \\
\% Fibre & Nd & 4.09 & 7.19 & 9.12 & 10.98 \\
\% Carbohydrate & 20.20 & 15.32 & 13.87 & 12.95 & 10.30 \\
Energy & 2.96 & 2.08 & 2.87 & 4.10 & 3.93 \\
\hline
\end{tabular}

$\mathrm{Nd}=$ Not detected

Table 1b: Rate of absorption of Protein, Carbohydrate and lipid in the gut of Parachanna obscura during the period of study

\begin{tabular}{lllll}
\hline Nutrients & Foregut & Midgut & Hindgut & Total absorption \\
\hline \% Protein & 58.48 & 13.98 & 3.97 & 76.43 \\
\%Carbohydrate & 24.16 & 7.18 & 4.55 & 35.89 \\
\%Lipid & 14.71 & 7.19 & 3.27 & 25.17 \\
\hline
\end{tabular}

Table 2a: Proximate composition of the stomach content of Clarias gariepinus collected from Ogbese River

\begin{tabular}{|c|c|c|c|c|c|}
\hline Parameters measured & Stomach & Foregut & Midgut & Hindgut & Feaces \\
\hline$\% \mathrm{ASH}$ & 3.00 & 30.50 & 40.69 & 41.08 & 45.56 \\
\hline$\%$ Moisture content & 2.41 & 9.50 & 11.36 & 11.65 & 12.56 \\
\hline$\%$ Crude Protein & 60.87 & 36.14 & 22.02 & 19.50 & 15.58 \\
\hline$\%$ Fat & 3.30 & 2.84 & 2.60 & 2.49 & 1.85 \\
\hline$\%$ Fibre & $\mathrm{Nd}$ & 1.02 & 5.73 & 8.78 & 10.56 \\
\hline$\%$ Carbohydrate & 30.42 & 20.00 & 17.60 & 16.50 & 13.89 \\
\hline Energy kcal/g & 2.83 & 1.89 & 2.51 & 4.49 & 3.36 \\
\hline
\end{tabular}

$\mathrm{Nd}=$ Not detected

Table 2b: Rate of absorption of protein, carbohydrate and lipid in the gut of Clarias garieapinus during the period of study

\begin{tabular}{lllll}
\hline Nutrients & Foregut & Midgut & Hindgut & Total absorption \\
\hline \% Protein & 40.63 & 23.20 & 4.14 & 67.97 \\
\%Carbohydrate & 34.25 & 7.89 & 3.62 & 45.76 \\
\%Lipid & 13.93 & 7.27 & 3.33 & 24.53 \\
\hline
\end{tabular}

Table 3: Anova table of nutrient composition (\%) of the fish species from Ogbese River

\begin{tabular}{|c|c|c|c|c|c|c|c|}
\hline Sample & Ash & $\mathrm{MC}(\%)$ & $\mathrm{CP}(\%)$ & Fat $(\%)$ & Fiber $(\%)$ & $\mathrm{CHO}(\%)$ & Energykcal/g \\
\hline Parachanna obscura & $36.40^{\mathrm{a}}$ & $8.80^{\mathrm{c}}$ & $27.27^{\mathrm{b}}$ & $4.65^{\mathrm{d}}$ & $6.27^{\mathrm{d}}$ & $14.52^{\mathrm{c}}$ & $3.08^{\mathrm{d}}$ \\
\hline Clarias gariepinus & $32.16^{\mathrm{a}}$ & $9.49^{c}$ & $30.82^{\mathrm{a}}$ & $2.57^{\mathrm{c}}$ & $5.21^{\mathrm{c}}$ & $19.68^{b}$ & $3.02^{\mathrm{c}}$ \\
\hline
\end{tabular}

NOTE: Column with the same letter are not significantly different $(\mathrm{p}>0.05)$.

Note: $\mathrm{MC}=$ Moisture Content, $\mathrm{CP}=$ Crude Protein, $\mathrm{CHO}=$ Carbohydrate. 


\section{Discussion}

The major nutrients in the diet of the two species, Parachanna obscura and Clarias gariepinus from Ogbese River, Ekiti state is protein irrespective of size of the fish. This is so due to the fact that the diet of the species in the river is dominated by animal materials mainly on fish and insects. Similar observation has been reported by (Idowu, 2011) in Hepsetus odoe. Also Ugwumba (1996) made similar observation in Heterotis niloticus in Awba Lake.

More protein seems to have entered the body tissues of both species than carbohydrate and lipid. Protein from animal origin was the major component of the ingested food in both species. It is established that the activity of digestive enzymes in fish correlates with the nature of its food (Idowu, 2011). In omnivorous fish like Heterotis niloticus whose intestinal amylase is capable of releasing about $10 \mathrm{mg}$ of reducing sugar at optimum $\mathrm{pH}$ of 8.45 unlike herbivorous fish like Sarotherodon melanotheron which have a strong amylase activity and that intestinal amylase is capable of releasing about $20 \mathrm{mg}$ of reducing sugar at optimum $\mathrm{pH}$ of 8.45 (Ugwumba, 1996). Nikolsky (1963) reported that amylase activity in a carnivorous fish can be 150 times weaker and lesser than that of an herbivorous fish.

It is seen that percentage absorption was higher for protein than for carbohydrate and lipid in both fish species. Protein was more absorbed across sections of intestines for both species. The fact that total absorption of protein in Parachanna was $76.4 \%$, carbohydrate $35.9 \%$ and lipid $25.2 \%$ means that $23.6 \%$ protein, $64.1 \%$ carbohydrate and $74.8 \%$ of lipid consumed were lost. Likewise in Clarias gariepinus, total protein that was absorbed was $\sim 68 \%$, carbohydrate $45.8 \%$ and lipid $24.5 \%$ which deduce that $32.0 \%$ protein, $54.2 \%$ carbohydrate and $75.5 \%$ lipid that was consumed were probably lost. In both species, the amount of carbohydrate and lipid absorbed may reflect the lower capability for digestion of carbohydrate and lipid than protein. Protein is the most important diets for Parachanna obscura. Its short intestine favored digestion of flesh materials which increase the digestion and absorption of protein, which is further proofed by the value of protein which is $76.4 \%$. Clarias gariepinus in Ogbese River, an omnivorous fish but fed mainly on food materials from animal origin, which is further proofed by the value of protein which is $68.0 \%$. This denotes that Parachanna obscura absorb more protein than Clarias gariepinus. Diet rich in protein may be more useful to both species than one rich in carbohydrate and fat. This information will be useful during artificial feed formulation for culturing any of these two species.

In this study, the nutrients in the two species were significantly different from each other. Through statistical analysis protein value is $27.27^{\mathrm{b}}$ for
Parachanna obscura and $30.82^{\text {a }}$ for Clarias gariepinus, the carbohydrate value is $14.52^{\mathrm{c}}$ for Parachanna obscura and $19.68^{\mathrm{b}}$ for Clarias gariepinus and lipid value is $4.65^{\mathrm{d}}$ for Parahanna obscura and $2.57^{\mathrm{c}}$ for Clarias gariepinus. This could be due to differences in their food items and feeding habits.

Absorption and assimilation of nutrient is known to vary with fish species. It has been discovered that different species belonging to different families and genera, they absorb their food in a diverse manner (Bungher, 1995). Different fish species living in different habitats survive, live and depend on things available for them in their habitat. It has been confirmed and established by many authors that the type of food materials that is present in the environment of fish determines the type of absorption. Indolise (1992) stated that absorption of food in fish mainly depend on the food materials available. Bowen (1981) reported that Oreochromis mossambicus assimilated $63 \%$ organic matter, $77 \%$ protein and $63 \%$ carbohydrate in its food implying that $37 \%$ organic matter, $23 \%$ protein and $37 \%$ carbohydrate were lost. Tilapia rendalli assimilated 63$70 \%$ of the dry weight in the apical segment of Ceratophyllum demersum thus losing 30-37\% (Caulton, 1978). Oreochromis niloticus assimilated about $50 \%$ and $80 \%$ of carbon in green and blue- green algae, thus losing $50 \%$ and $20 \%$ respectively (Moriarty, 1973). Similar to what Torchel (1997) reported. The author used Oreochromis mossambicus and fed them with plant material (algae), he discovered that about $60 \%$ and $70 \%$ of carbon in green and blue-green algae were absorbed and assimilated, thus losing $40 \%$ and $30 \%$ respectively. Hepsetus odoe absorbed about $72 \%$ of protein, $63 \%$ of carbohydrate and $51 \%$ of lipid thus losing $28 \%$ of protein, $37 \%$ of carbohydrate and $49 \%$ of lipid (Idowu, 2011).

This study shows that protein have higher percentage absorption than other nutrients present. Some authors that have reported that carbohydrate have higher percentage absorption than other nutrients. Ugwumba (1996) discovered that Serathoredon melanotheron absorbed about $58 \%$ of carbohydrate, $50 \%$ of protein and $54 \%$ of lipid. In Heterotis niloticus, about $65 \%$ protein, $40 \%$ carbohydrate and $78 \%$ lipid consumed were absorbed, thus 22-60\% were lost (Ugwumba, 1996).

This present study confirmed previous report that the absorptive capacity varies along the intestine. The fore and midgut were the main sites of absorption of food in Parachanna obscura and Clarias gariepinus. Over half of the protein, carbohydrate and lipid in the ingested food found in the stomach were absorbed in the foregut. There was little absorption of lipid in the hindgut. A similar observation was made by Ugwumba (1996) in Sarotherodon melanotheron. Likewise Al-Hussainin and Kholy (1953) reported similarly in cyprinids and Akintunde (1982) in Sarotherodon galilaeus. Fat absorption mainly occurred in the midgut of these fishes. 
Absorption of food has also been reported to occur mainly in the foregut (Bowen 1981, Idowu 2011) as well as in the mid gut (Al-Hussainin and Kholy, 1953) or in the pyloric caeca depending on the species. Generally, there is little or no absorption of food in the hindgut.

In Parachanna obscura, less than 5\% absorption of protein, carbohydrate and lipid occurred in the hindgut. Likewise in Clarias gariepinus, only about 5\% of protein and carbohydrate were absorbed and only about $3 \%$ of lipid was absorbed in hindgut (Table $1 \mathrm{~b}$ and $2 \mathrm{~b}$ ). This may be due to the fact that the surface area for absorption of food in the foregut and midgut may have been increased by the numerous and compact mucosal folds in these sections of the gut compared to the hindgut where the folds are less numerous and wide apart (Ugwumba, 1996). The mucosa folds are known to function in absorption of food.

It was not possible to say whether absorption of food occurred in the stomach of Parachanna obscura and Clarias gariepinus since the chemical composition of food in its stomach was not compared with that in the environment. However it is possible for absorption of food to occur in the stomach of fish. Absorption of food was reported in the stomach of dog fish. In dog fish $35 \%$ protein was absorbed.

\section{Conclusion}

Dietary protein, carbohydrate and lipid contents of the food as well as the absorptive capacity decrease across the sections of intestine of both fish species. it is confirmed that protein has higher absorption in these two species than other nutrients in Ogbese River. The nutrients (protein, carbohydrate and lipid) in both fish species are significantly different from each other. Information on their dietary composition and nutrient level will provide base- line information useful in artificial food formulation and culture of suitable live organisms for the species during culture of either species.

\section{Acknowledgement}

We sincerely acknowledge the efforts of the laboratory Technologists of the Zoology and Environmental Biology laboratory during the course of the bench work of this study

\section{Funding Information}

This study was funded by the authors.

\section{Authors' Contribution}

Eunice O. Idowu: Handled the proximate analysis of stomach content of the Fish samples and also contributed financially to the research.
Folasade A. Ola-Oladimeji: Handled the statistical analysis of the results obtained.

Dolapo F. Odeyemi: Collation of results and compilation of the manuscript.

Akintayo Joshua Oluwaseun: Collection of fish samples.

Adewumi Adejoke: Supervised the estimation of food absorption along the gut.

Josephine B. Edward: Supervised the proximate analysis of stomach content of the fish samples.

\section{Conflict of Interest}

There is no conflict of interest

\section{References}

Abowei, M. and D. Ekubo, 2011. Diet composition on fish species from the southern continental shelf of Colombia. Naga ICLARM Q., 25: 23-29.

Adewumi, A.A., E.O. Idowu and S.T. Bamisile, 2014. Food and feeding habit of Clarias gariepinus (Buchell 1822) in Ogbese River, Ekiti State, Nigeria. Anim. Res. Int., 11: 2041-2047.

Adeyemi, S.O., 2009. Food and feeding habits of some commercially important fish species in Gbedikere Lake, Bassa, Kogi, State, Nigeria. Int. J. Lakes Rivers, 2: 31-36.

Ahmed, 2013. Distribution, food and feeding habits of a catfish, Clarias gariepinus (Burchell 1822) in Opa Reservoir, Ile Ife, Nigeria. Sci. Focus, 10: 62-67.

Al-Hussainin, A.H. and A.A. Kholy, 1953. On the functional morphology of the alimentary tract of some omnivorous teleost fish. Proc. Egypt Acad. Sci., 9: 17-39.

Akintunde, E.A., 1982. Intestinal absorption by Sarotherodon galilaeus (Syn. Tilapia galileus) of Kainji Lake Nigeria. Proceedings of the 2nd Annual Conference of the fisheries Society of Nigeria, Jan. 25-27, Calabar, pp: 236-243.

Amber, B.A., 2013. Food, Feeding and Fecundity of the Giant Freshwater Prawn from Natural habitatin Sri Lanka. In: The First Asian Fisheries Forum, Maclean, J.L., L.B. Dizon and L.V. Hostillos (Eds.), Asian fisheries content analysis a review of methods and their application. J. Fish Biol., 17: 411-429.

Ameigheme, A.Y., 2005. The feeding habits and the morphology of the alimentary tract of some teleost living in the neighbuorhood of the marine biological station, Ghardaqa, Red Sea. Pub. Mar. Biol. Sta. Ghar., 5: 1-61.

Bligh, E.G. and W.J. Dyer, 1959. A rapid method of total lipid extraction and purification. Can. J. Blochm. Phys., 37: 911-917. DOI: 10.1139/y59-099 
Bord, S.C., 2013. The food and feeding habits of Hydrocynus forskahlii and Hydrocynus brevisin Lake Kainji, Nigeria. J. Fish Biol., 6: 349-363. DOI: $10.1111 /$ j.1095-8649.1974.tb04552.x

Bowen, S.H., 1981. Digestion and assimilation of periphytic aggregated by Tilapia Mossambica. Trans. Ani. Fish Sci., 110: 239-245. DOI: 10.1577/15488659(1981)110<239:DAAOPD>2.0.CO;2

Brunson, K.K., 1998. The black snakehead, Channa melasoma (Channidae). First record from Singapore. Raffles Bull. Zool., 38: 21-24.

Bungher, B.M., 1995. A bioenergetics model for Juvenile snakehead (Channa striatus). Environ. Biol. Fish, 50: 308-318.

Caulton, M.S., 1978. The importance of habitat temperatures for growth in the tropical cichlid Tilapia rendalli. Boulenger. Fish Biol., 13: 99-112. DOI: 10.1111/j.1095-8649.1978.tb03417.x

Clark, J., 1983. A preliminary Investigation of the Digestive Enzymes of thee Dover Sole (Solea soea). 1st Edn., Herio-tatt University, Edinburgh, pp: 30.

Elliott, J.P. and D.R. Bellwood, 2003. Alimentary tract morphology and diet in three coral reef fish families. J. Fish Biol., 63: 1598-1609.

DOI: $10.1111 / \mathrm{j} .1095-8649.2003 .00272 . \mathrm{x}$

Fiogbe, 2013. Dietary regulation of activities and mRNA levels of trypsin and amylase in sea bass (Dicentrarchus labrax) larvae. Fish Physiol. Biochem., 19: 145-152. DOI: 10.1023/A:1007775501340

George, H., J. Olli, K. Hjelmeland and A. Krogdahl, 2009. Effects on nutrient digestibilities and trypsin in pyloric caeca homogenate and intestinal content. Comp. Biochem. Physiol., 109: 923-928.

Idowu, E.O., 2011. Absorption of food in African pike Hepsetus odoe (Block, 1974) in Ado Ekiti Reservoir, Ekiti State, Southwestern Nigeria. J. Agr. Sci. Tech- Iran, 49: 472-475.

Indolise, G., 1992. Effects of dietary phosphatidylcholine on postprandial plasma levels and digestibility of lipid in common carp (Cyprinus carpio). Brit. J. Nutr., 100: 512-517.

DOI: $10.1017 / \mathrm{S} 0007114508904396$

Kaushik, N.K. and H.B. Hynes, 1968. Experimental study on the role of autumn-shed leaves in aquatic environment. J. Ecol., 65: 229-243. DOI: $10.2307 / 2258076$

Miller, G.L., 1959. Protein determination for large numbers of samples. Analyst. Chem., 31: 964-964. DOI: 10.1021/ac60149a611

Moriarty, E.J., 1973. The physiology of digestion of blue-green algae in Tilapia Niloticus. J. Zonl. Lond., 171: 25-39.

DOI: $10.1111 / \mathrm{j} .1469-7998.1973 . t b 07514 . x$
Nikolsky, G.V., 1963. The Ecology of Fishes. 2nd Edn., London and New York, pp: 352.

Olojo, E.A.A., K.B. Olurin, G. Mbaka and A.D. Olumemino, 2005. Food and feeding habit of the African catfish, Clarias gariepinus. African J. Biotech., 4: 117-122.

Peter, J., P.O. Ajah, M.N. Georgewill and M.O. Ajah, 2004. The food and feeding habits of five freshwater and brackish-water fish species in Nigeria. Afr. J. Aquat. Sci., 31: 313-318. DOI: 10.2989/16085910609503901

Philips, D., 1996. Nutrition, ecology and nutritional ecology: Toward an integrated framework. Func. Ecol., 23: 4-16. DOI: 10.1111/j.1365-2435.2009.01522.x

Platell, K. and L. Polter, 2001. Nutrient digestibility values of a test diet determined by manual feeding and self-feeding in rainbow trout and common carp. Fish. Sci., 67: 355-357.

DOI: $10.1046 /$ j.1444-2906.2001.00251.x

Portella, M.C. and K. Dabrowski, 2008. Diets, Physiology, Biochemistry and Digestive Tract Development of Freshwater Fish Larvae. In: Feeding and Digestive Functions of Fishes, Cyrino, J.E.P., D.P. Bureau and B.G. Kapoor, Science Publishers, Enfield, New Hampshire, US, pp: 227-279.

Rabanal, B., D.M. Casirola and R.P. Ferraris, 2004. Intestinal absorption of water-soluble vitamins in rainbow trout (Oncorhynchus mykiss). Comp. Biochem. Physiol. A, 116: 273-279. DOI: $10.1016 / \mathrm{S} 0300-9629(96) 00209-5$

Russo, T., C. Costa and S. Cataudella, 2007. Correspondence between shape and feeding habit changes throughout ontogeny of gilthead sea bream (Sparus aurata). J. Fish Biol., 71: 629-656. DOI: 10.1111/j.1095-8649.2007.01528.x

Schineider, P., 1990. Physiological modulation of iron metabolism in rainbow trout (Oncorhynchus mykiss) fed low and high iron diets. J. Exp. Biol., 207: 75-86. DOI: $10.1242 /$ jeb.00712

Tanaka, G., R. Victor and B.O. Akpocha, 1981. The biology of snakehead, Channa obscura, in a Nigerian pond under monoculture. Aquaculture, 101: 17-24. DOI: 10.1016/0044-8486(92)90228-D

Torchel, N., 1997. Food and feeding habits of Clarias mossambicus from four areas in the Lake Victoria basin, East Africa. J. Environ. Biol., 10: 69-76. DOI: 10.1007/BF00001663

Ugwumba, A.A., 1996. The food and feeding ecology of Sarotherodon melanotheron (Rupell), in a small freshwater reservoir in Ibadan, Nigeria. Arch. Hydrobiol., 124: 367-382. 